\title{
Robin Hood İsimli Eserlerde Çocuğa Göre Olmayan Ögeler
}

\author{
DOI: 10.26466/opus.682939
}

*

\begin{abstract}
Yakup Alan *
* Dr. Öğr. Üyesi, Kilis 7 Aralık Üniversitesi, Muallim Rıfat Eğitim Fakültesi, Türkçe Eğitimi Ana Bilim Dalı, Kilis
\end{abstract}

E-Posta: alanyakup@gmail.com

ORCID: 0000-0002-9888-1357

\section{Öz}

Hemen her çocuğun bildiği kahramandır Robin Hood. Robin, ormanda yaşayan ve Hırsızlar Prensi olarak da anılan bir kahraman olarak çıkar karşımıza. Çocuk edebiyatı ürünlerinin içinde yer alan eserin kahramanı Robin, haksızlıklara ve adaletsizliğe kendi yöntemleriyle karşı çıkmaya çalışarak "Haksızlık ve adaletsizlik varsa hırsızlık yasaldır." mesajın ulaştırmaktadır okuyucusuna. Robin Hood adl eserlerin çocuğa görelik ilkesine uygun olmayan yönlerinin belirlenmesi amactyla hazırlanan bu araştırmada nitel araştırma yöntemlerinden doküman incelemesi kullanılmıştır. Araştırmada kullanılan yayınlar; kolay ulaşılabilirlik, fiyatının uygun olması ve en çok satılan Robin Hood kitapları arasında yer alması gibi kriterler dikkate alınarak ölçüt örnekleme yöntemiyle belirlenmiştir. Bu bağlamda beş farklı yayınevi tarafindan basılan yayınlar temin edilmiştir. Bu yayınlar belirlenen temalara göre incelenmiş ve toplanan veriler betimsel analize tabi tutulmuştur. Ortaya çıkan bulgular frekanslar hâlinde sunulmuş, ayrica bulguları desteklemesi amacıyla eserlerden doğrudan alıntılar yapılmıştır. Çalışmanın sonucunda Robin Hood adlı eserlerin içki, şiddet, yalan, hakaret ve hırsızlı gibi olumsuz birçok iletiyi bünyesinde barındırdıkları ortaya çıkmıştır.

Anahtar Kelimeler: Robin Hood, çocuk edebiyatı, çocuğa görelik. 


\title{
Elements that are Not for the Child in Robin Hood
}

\begin{abstract}
Robin Hood is a hero known almost by all children. Robin is confronted as a noble gentleman burglar and even as a Prince of Burglars living in woods. The hero of the work belonging to children literature genre, Robin fights with injustice and unfairness with his own style and conveys the message "if there is injustice and unfairness, then theft is legal" to his readers In this research, document analysis, one of the qualitative research methods, was used. Works used in the study; it is determined by criterion sampling method considering the criteria such as easy accessibility, affordable price and being among the best-selling Robin Hood books. In this context, books published by five different publishing houses were provided. These works were examined according to the themes determined and the data collected were subjected to descriptive analysis. The resulting findings were presented in frequencies, and direct quotations from the works were made to support the findings. As a result of the study, it is revealed that the works named Robin Hood contain many negative messages such as drink, violence, lies, humiliation and theft.
\end{abstract}

Keywords: Robin Hood, children literature, proper for child 


\section{Giriş}

Toplumları oluşturan unsurlar bireylerdir. Bir toplumun gelişmişlik düzeyi ile o toplumda yaşayan bireylerin gelişmişlik düzeyi arasında sıkı bir bağ vardır. Eğitimin başlangıcından itibaren en önemli konularından biri nitelikli insan tipi yetiştirme olmuştur (Karatay, 2011). Nitelikli insanın en önemli özelliklerinden biri ise değerlerini benimsemiş ve onları yaşayan birey olmasıdır. Özellikle teknolojinin gelişmesiyle, insanlar arası ilişkilerin -neredeyse- sadece teknolojik aletlerle gerçekleşmeye başladığı günümüzde, değerlerini benimsemiş bireylerin yetiştirilmesinde ailelere, çevreye ve özellikle eğitimcilere büyük yük düşmektedir.

Gelişmiş bir toplum hâline gelmenin yollarından biri iyi eğitimli bireyler yetiştirmektir. Çocuklara doğruluk, sorumluluk, yardımseverlik, başkalarına saygılı olma, sevgi, dürüstlük, çalışkanlık, cesaret, güvenirlilik, kararlılık vb. değerlerin öğretilmesinin gerekliliğini kabul eden bir toplum yapısı vardır (Alan, 2012). Bu değerleri çocuklara kazandırmanın yollarından biri de çocuk edebiyatı ürünlerinden yararlanmaktır. Bu eserlerden yararlanarak değerlerini benimsemiş ve onları yaşayan bireyler ortaya çıkarılmaya çalışıldığında; anlayışla yaklaşan, ilgili, ahlaki ilkelere sahip, üretmeyi seven, yeteneklerini iyiye kullanan, güzel işler yapan ve hayatı bir amaç uğruna yaşayan iyi çocuklar görmek mümkün olacaktır (Gökçek, 2007, s. 8).

Çocuk edebiyatı ürünlerinin, çocuklara beklenen bu katkıları sunabilmeleri için çeşitli özellikleri taşımaları gerekmektedir. Çocuğa görelik ilkesi olarak adlandırılan bu temel özellik çocuğun bakış açısını, çocuğun dünyasını, çocuğun bilişsel, duyuşsal ve fiziksel özelliklerini dikkate almayı gerektiren temel unsurlardan biridir (Aktaş ve Uzuner Yurt, 2017). Bu açıklamadan hareketle çocuğa görelik ilkesinin eğitim açısından çok kapsamlı bir ilke olduğunu söylemek mümkündür. Fakat konuya edebiyat açısından bakıldığında ise çocuğa görelik ilkesinin sınılarının daraldığını ve çocuklar için hazırlanmış kitapların çocuğa göre olup olmadığını belirlemeye çalışma sürecini ifade ettiği söylenebilir (Demirel ve Kökçü, 2019). Bu bağlamda çocuk edebiyatı açısından çocuğa görelik ilkesini "çocuklar için hazırlanan edebiyat ürünlerinde çocukların büyüme ve gelişme çağlarına, psikolojilerine, sözcük ve kavram bilgilerine, algilama düzeylerine uygun bir duyarlılık" (Şirin, 2000, s. 19) şeklinde tanımlamak mümkün olacaktır. Özdemir (1983) de çocuğa görelik ile çocukların gelişim özellikleri arasında sıkı bir bağ olduğundan ve bu bağın 
devam edebilmesi için çocukların ilgisi, beklentileri, gereksinimleri, dil özellikleri gibi unsurlara dikkat etmenin zorunlu olduğundan bahsetmektedir. Çocuğa görelik ilkesine uygun hazırlanmış eserler, değerleri içinde barındıran materyallerdir. Bu eserler aracılığıyla bireyler iyi olana, güzel olana ve doğruya yönelirler. Bu nedenle edebi eserler, değerlerin insanlar tarafından benimsenmesi ve kökleşmesi açısından çok önemli roller oynarlar (Kavcar, 1999, s. 6).

Güleryüz'e (2003) göre çocuğa görelik ilkesinin dikkate alınmasıyla oluşturulan metinlerde bulunması gereken özellikler şunlardır:

- Metinler çocuğun seviyesine uygun olmalıdır.

- Metinler çocuğun ilgi ve ihtiyaçlarına uygun olmalıdır.

- Doğrudan ders vermemelidir. Çocuk doğruya kendisi ulaşmalıdır.

- Çocuğun dil evrenine uygun olmalıdır.

- Çocuk gerçekliğine duyarlı olmalıdır.

- Çocuğun hislerine dokunabilmelidir.

- Estetik haz uyandirmalıdır.

- Okuma isteği uyandırmalıdır.

$\mathrm{Bu}$ özelliklerin dikkate alınmasıyla hazırlanan eserler, bireyleri belirli hedeflere ulaştırmada aileye, eğitimcilere ve topluma katkıda bulunabilir. $\mathrm{Bu}$ hedeflerden bazıları aşağıdaki gibi sıralanabilir (Gönen ve Veziroğlu, 2013; Oğuzkan, 2013):

- Çocukların ruhsal ihtiyaçlarını karşılama.

- Çocukları yaşam gerçeklerine hazırlama.

- Çocukta benlik algısı geliştirme ve sosyal değerleri aktarma.

- Çocuklara kültürel değerleri aktarma.

- Dili doğru ve etkili kullanmayı öğretme.

- Kitap sevgisi ve okuma alışkanlığı kazandırma.

- Eleştiri gücünü ve yaratıcılığın geliştirme.

- Çocukları eğlendirme.

Edebi eserlerin çocuk kitabı sayılabilmesi ve bireyleri bu hedeflere ulaştırabilmesi için Sever'e (2012, s. 145) göre belirli ölçütler vardır. Bunlar; eserin konusu, dili ve anlatımıdır. Ayrıca yine hedeflere ulaşabilmek için hazırlanan eserlerin konularının da bazı özellikleri barındırması gerekmektedir. Çocuk 
edebiyatı ürünleri sevgi, barış, iyilik, dürüstlük, iyimserlik gibi konular etrafında yazılmalı ve çocuklara insan, doğa, hayvan sevgisi kazandırmalıdır (Aktaş ve Uzuner Yurt, 2017). Ayrıca çocuk edebiyatı ürünlerinde şiddet, korku, düşmanlık, ırkçlık, cinsiyetçilik, kötümserlik, hırsızlık, içki, kumar, dolandırıcilık, kin, nefret, argo gibi unsurlara da yer verilmemelidir (Altınköprü, 2005; Demirel, 2011, s. 53; Enginün, 2006; Nas, 2004, s. 91; Oğuzkan, 1997, s. 51). Millı̂ Eğitim Bakanlığı da ders kitaplarına alınması gereken metinlerin özelliklerini sıralarken metinlerin argo ve küfür, olumsuz örnek oluşturabilecek davranışlar, cinsellik, şiddet vb. içeren unsurları barındırmaması gerektiğinden bahsetmektedir (MEB, 2019). Ders kitabına alınacak metinlerde aranan bu niteliklerin çocuk kitaplarında aranmaması ise mümkün değildir.

Robin Hood İngiliz halk hikâyelerinde geçen ve 12. yüzyılda yaşadığ 1 tahmin edilen İngiliz halk kahramanıdır. Halk hikâyelerinin derlenmesiyle oluşturulan birçok kaynakta Robin, Karal John'a karşı olan bir haydut olarak ele alınır. Robin Hood'un haksızlıklara karşı geliştirmiş olduğu mücadele şekli onun İngiliz kahramanı olmasında önemli bir etkiye sahiptir. Robin'in mücadele şekli birçok kitap ve oyuna konu olmuştur. Sir Walter Scott, Howard Pyle ve Roger L. Green Robin Hood'un hayatını ve yaşadıklarını kaleme alan yazarlardan bazılarıdır. Halk hikâyelerinin derlenmesiyle oluşturulan Robin Hood isimli eserlerde bazı açılardan benzerlikler bulunmasına rağmen birçok açıdan farklılıklar vardır. Örneğin bir eserde Robin'in kanun kaçağı olmasının nedeni bir korucuyu öldürmesine dayandırılırken diğerinde askerlerin annesini öldürmelerine dayandırılmıştır. Veya bir eserde Robin bir çiftçi olarak gösterilirken başka bir eserde soylu bir kişinin oğlu olarak verilmiştir. Robin Hood derlemelerinde çevirisi yapılan kitaplardan en yaygın olanı Howard Pyle tarafından oluşturulmuştur. Fakat Roger L. Green'in derlemesi de çevirisi yapılan diğer Robin Hood kitabıdır. Hikâyelerden oluşan derlemelerden bazı bölümlerin çıkarılması konu bütünlüğünü etkilemediği için yapılan çevirilerde de farklılıklar vardır. Hem derleyenler tarafından farklı şekilde sunulması hem de bazı çevirilerde bölümlerin tamamının alınmaması farklı Robin Hood karakteriyle karşılaşmamıza sebep olabilmektedir.

Alanyazında çocuk edebiyatı ürünlerinin değerlendirilmesine yönelik çok sayıda araştırma bulunmaktadır. Fakat Robin Hood adlı eserlerin içerik yönünden incelenmesine yönelik bir araştırmaya rastlanmıştır. Kardaş ve Kar- 
daş (2018) tarafından yapılan bu araştırmada en çok okunan bazı çeviri eserlerin incelemesi yapılmıştır. Bunun dışında çocuk edebiyatı ürünlerinin karakter eğitiminde kullanılmasına veya karakterlerin taşıması gereken özelliklere yönelik çalışmalar mevcuttur. Karataş (2014) çocuk edebiyatında karakter kavramını ve karakterlerde bulunması gereken özellikleri incelemiş, Karatay (2011) ve Karatay, Destebaşı ve Demirbaş (2015) da çocuk edebiyatı ürünlerinin karakter eğitiminde kullanımına yönelik araştırma yapmışlardır. Ayrıca farklı çocuk edebiyatı ürünlerini incelemeye yönelik araştırmalar da mevcuttur (Aktaş ve Uzuner Yurt, 2017; Bilgin, 2011; Karakuş Tayşi, 2019; Kuru ve Keklik, 2016; Özdemir ve İdi Tulumcu, 2017; Öztürk ve Giren, 2016; Sever, 2002; Turan, 2006; Varışoğlu ve Tuzcuoğlu Aksin, 2019; Yılmaz, 2016; Yılmaz ve Destegüloğlu, 2019). Bu araştırmalar incelendiğinde, çocuk edebiyatı ürünlerinin çocuğa görelik ilkesi açısından değerlendirildiği veya eserlerin olumlu/olumsuz yönlerinin ortaya konulmaya çalışıldığı görülmektedir. Bu araştırmada da Robin Hood adlı eserlerin çocuk edebiyatı eserlerinde bulunmaması gereken içerik özelliklerine göre incelemesi yapılmıştır. Araştırmanın, Robin Hood adlı eserlerin incelenmesine yönelik fazla araştırmanın olmaması ve bu kitapların çok satılan çocuk edebiyatı ürünleri arasında olması nedeniyle ilgili kişilere kitaplar hakkında yol göstermesi açısından faydalı olacağı düşünülmektedir.

Bu çalışmanın amacı, Robin Hood isimli eserlerin "çocuğa göre olmayan yönleri" açısından incelenmesidir. Bu temel amaç doğrultusunda araştırmada aşağıdaki sorulara cevap aranmıştır:

1. Robin Hood isimli eserlerde yer alan çocuğa göre olmayan unsurlar nelerdir?

2. Robin Hood isimli kitapların farklı basımlarında çocuğa göre olmayan unsurlar nasıl geçmektedir?

\section{Yöntem}

\section{Araştırma Modeli}

Araştırmada doküman incelemesi kullanılmıştır. Doküman incelemesi, araştırılması hedeflenen olgu ve olgular hakkında bilgi içeren yazılı materyallerin 
analizini kapsamaktadır (Yıldırım ve Şimşek, 2016, s. 189). Çalışmada doküman incelemesinin kullanılma nedeni incelenen eserlerin temel veri kaynağ 1 olmasidir.

\section{İncelenen Dokümanlar}

Robin Hood adlı eserlerin ele alındığı çalışmada incelenen materyaller, ölçüt örnekleme yöntemi dikkate alınarak oluşturulmuştur. Ölçüt örneklemede esas anlayış, önceden belirlenmiş ölçütleri karşılayan durumların çalışılmasıdır. Ölçütler araştırmacı tarafından oluşturulabildiği gibi daha önceden hazırlanmış bir ölçüt listesi de kullanılabilir (Yıldırım ve Şimşek, 2016, s. 122). Çocuk edebiyatında kahramanların önemli rolleri olduğundan hareketle çalışmada, "herkes tarafından kabul edilen bir kahramanın taşıyabileceği olumsuz özelliklerin neler olabileceği" ölçüt kabul edilmiş ve kahramanının herkes tarafından kabul görmesi açısından "Robin Hood" adlı eserin incelenmesine karar verilmiştir. Çalışmaya beş yayınevi tarafından basılan kitaplar dâhil edilmiştir. Yayınevlerinin seçiminde de kolay ulaşılabilir olması, fiyatının uygun olması ve kitap satıs sitelerinde en çok satılan Robin Hood kitaplarının arasında olması gibi ölçütler dikkate alınmıştır. Ayrıca seçilen eserlerin farklı derleyiciler tarafından kaleme alınan kitaplar olmasına da dikkat edilmiştir. Böylece hem herkesin kolay elde edebileceği hem de farklı yazarlar tarafından derlenen eserlerdeki kahramanın incelenmesi sağlanmıştır. Araştırmada beş farklı yayının incelenme nedeni ise Robin Hood'u farklı eserlerde anlatılan tüm yönleriyle ele almaktır. Çalışmada kullanılan eserlerle ilgili bilgiler Tablo 1'de sunulmuştur:

Tablo 1. Çalışmada kullanılan eserlerle ilgili bilgiler

\begin{tabular}{llll}
\hline Eser Adı & Çeviren / Uyarlayan & Sayfa Sayısı & Araştırmada kullanılan Kod \\
\hline Robin Hood & Erdal Çakıcıŏlu & 87 & RH1 \\
\hline Robin Hood & Ali Aydoğan & 125 & RH2 \\
\hline Robin Hood & Tanju Anapa & 166 & RH3 \\
\hline Robin Hood & İbrahim Faruk & 157 & RH4 \\
\hline Robin Hood & Bilgin Adalı & 269 & RH5 \\
\hline
\end{tabular}

\section{Verilerin Toplanması ve Analizi}

Başlangıçta eserler araştırmacı tarafından ikişer defa okunmuş ve eserler hakkında bir fikir edinilmiştir. Daha sonra belirlenen temaların ortaya çıkarılabilmesi amacıyla araştırmacı tarafından eserler tekrar okunmuş ve fişleme 
yapılarak veriler elde edilmiştir. Araştırmacının dışında başka bir uzman tarafından da rastgele seçilen bir kitabın incelemesi yapılmış ve güvenirlik açısından veriler karşılaştırılmıştır.

Elde edilen verilerin analizinde ise betimsel analiz kullanılmıştır. Bu analiz yöntemine göre veriler, daha önceden belirlenen temalara göre özetlenir ve yorumlanır. Betimsel analizde, doğrudan alıntılara sıkça yer verilir (Yıldırım ve Şimşek, 2016, s. 239). Çalışmada da elde edilen veriler çocuk edebiyatı eserlerinde bulunmaması gereken temalara (içki, şiddet, hakaret, yalan, hile, hırsızlık,) göre kodlanmış, frekansları belirlenmiş ve tablolar hâlinde sunulmuştur. Ayrıca verileri desteklemesi amaciyla da eserlerden örnekler verilmiştir.

Çalışmanın güvenirliğini sağlamak amacıyla da Miles ve Huberman'ın (1994) formülü kullanılmıştır. İki kodlayıcının yapmış olduğu kodlamaların ne derece örtüştüğüne bakılmış ve iki kodlayıcı arasındaki kodlama güvenirliğinin .83 olduğu tespit edilmiştir. Ortaya çıkan bu sonuç, kodlamaların güvenilir olduğunu göstermektedir.

\section{Bulgular}

Çalışmanın bu bölümünde incelenen eserlerde ortaya çıan veriler tablolar hâlinde sunulmuştur.

Robin Hood adlı eserde yer alan içki/alkol ögesine yönelik bulgular Tablo 2'de verilmiştir:

Tablo 2. Robin Hood adl eserlerde yer alan içki ögesine yönelik veriler

\begin{tabular}{|c|c|c|}
\hline Kod & Kitap & $f$ \\
\hline \multirow{5}{*}{ 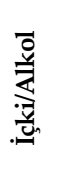 } & RH1 & 19 \\
\hline & RH2 & 3 \\
\hline & RH3 & 40 \\
\hline & RH4 & 65 \\
\hline & RH5 & 55 \\
\hline
\end{tabular}

Tablo 2' de eserlerde yer alan içki/alkol iletilerine yönelik bulgulara yer verilmiştir. Buna göre içinde içki veya alkole yönelik en fazla ileti barındıran eser RH4 kodlu eserdir. Toplam 65 farklı yerde içki veya alkol kullanımıyla ilgili veri eserde yer almaktadır. Bunu sırasıyla RH5 (55), RH3 (40), RH1 (19) ve RH2 (3) takip etmektedir. Çocuk edebiyatı eserlerinin, çocukları olumsuz 
yönde etkileyebilecek unsurlardan kaçınması gerektiği düşüncesinden hareketle incelenen eserlerin çocuklar için uygun olmadığı söylenebilir. Çünkü bu eserleri okuyan çocuklar içki/alkol iletileriyle sürekli karşılaşacak ve bunlara karşı çocuklarda özenti ortaya çkabilecektir. İçki/alkol iletisine yönelik örnekler şu şekildedir:

- İckisinden bir yudum alan tenekeci:

-Enfes bir şarap, dedi. Şimdiye kadar dudaklarımdan geçen en nefis içkinin bu olduğunu itiraf etmeliyim arkadaş. (RH4, 28)

- Atına bakılırken şövalye de üstündeki ağır zırhları çıkardı, elini yüzünü yıkadı, Robin ve adamlarmm sofrasina oturdu. Her şeyden bol bol vard, geyik eti, sülün, kimi küçük av kuşları, çörek ve bira. Marian arkada bekleyip Robin'in ve konuğun kadehlerine şarap dolduruyordu. $(R H 5,184)$

- Gece Robin ve adamlarmın, güzel kraliçelerine saygılarmı sundukları gizli alanda ziyafet ve şenlik vardr. Yemekte elbette kızarmış geyik eti eksik değildi. Masanın üzerinde büyük şarap şişeleri, kahverengi bira kupalar ve daha pek çok lezzetli yiyecek stralanmıştı. $(\mathrm{RH} 3,68)$

- -Soluk almak mı! Hayır! Bir şey içmek ister misin, diye sorsaydn, evet derdim. Bir testi şarap ya da bira olsaydl, keyfime diyecek olmazdl. (RH1, 35)

- Az önce tokadr yiyen asker:

-Dolabın kapısı da kilitliydi, dedi. Kırıp açınca bu şarapları bulduk.

-Neşesi yerine gelen komutan şişelerden birini eline alp, - vali gelinceye kadar hem eğlenir, hem de ısınırı. Haydi bakalım, herkese şarap verin. (RH2, 74)

Robin Hood adlı eserde yer alan şiddet ögesine yönelik bulgular Tablo 3 'te verilmiştir:

Tablo 3. İncelenen eserlerde yer alan şiddet ögesine yönelik bulgular

\begin{tabular}{|c|c|c|}
\hline Kod & Kitap & $f$ \\
\hline \multirow{5}{*}{ 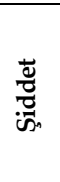 } & RH1 & 6 \\
\hline & RH2 & 18 \\
\hline & RH3 & 35 \\
\hline & RH4 & 45 \\
\hline & RH5 & 32 \\
\hline
\end{tabular}

Eserlerde yer alan şiddet ögesine yönelik bulgular Tablo 3 'te verilmiştir. Elde edilen bulgulara göre şiddet iletilerini içinde en çok barındıran eser RH4 (45) kodlu eserdir. Bu eseri sirasiyla RH3 (35), RH5 (32), RH2 (18) ve RH1 (6) 
takip etmektedir. İçinde şiddet barındırmayan eser yoktur. Şiddet ögesi genellikle karşımıza savaş, kavga, zorbalık şekillerinde çıkmaktadır. Eserlerde yer alan şiddet ögesine yönelik örneklerden bazıları şöyledir:

- Hasmının kürek kemikleri arasına güçlü bir darbe indiren Robin, yabancmın her tarafinın kanlar içerisinde kalmasına neden oldu. Robin o kadar güçlü vurmuştu ki, yabancının köprüden yuvarlanmasına ramak kalmış, fakat son anda kendini toparlamıştı. $($ RH4, 14)

- SSerif kölenin ağzina sert bir tokat atarak, "Sus köpek!" diye bağırdı. $(R H 3,14)$

- Densiz adam babamin her şeye burnunu sokan aptal bir bunak olduğunu söylemekteydi. Hemen pencereden atlayıp "her şeye burnunu sokan aptal sensin!" diye bağırarak yanına gittim. "Bu küstahlı̆̆ın ve aptallığın için!" diyerek, düşündüğümden de sert, bir yumruk indirdim. Adam yere yuvarlandı ve bir daha kalkamadı. Bоynu mu kırılmıs nedir... (RH5, 77)

- Allan'a en yakn olan askerler, yedikleri birer okla yere serildiler. Sonra ikinci bir ok dalgası havada ıslık sesi çıkararak gelmiş ve bu sefer de Allan ile kapı arasında yer alan askerlere isabet etmişti. (RH2, 107)

- Jack, bütün becerisine karşın, sopasım Fıçı'ya dokundurmayı başaramıyordu. Üstelik, böğrüne iki de sopa yemişti. Bu duruma çok öfkelendi ve karşı saldırıya geçmek istedi ama tam o sırada kendi oyunuyla yenik düştü. Fıçı, sopasını okçunun kafasina indirdi. $($ RH1, 45)

Robin Hood'u kahraman yapan özelliklerinden biri kötü insanlarla şavaşmasıdır. Ancak savaşın veya şiddetin olumlu bir durum gibi gösterilmesi veya haksızlıklarla mücadele ederken her durumda şiddete başvurulması çocuk edebiyatı açısından uygun değildir. Robin Hood'un veya arkadaşlarının da her durumda şiddete başvurmaları, konuşarak çözüme ulaşmayı tercih etmemeleri onların olumsuz bir özelliği olarak karşımıza çıkmaktadır. Köprüden karşıya geçmesi için yol vermeyen, önce kendisi geçmek isteyen bir yabancıyla dövüşmesi ve onu kanlar içinde bırakması bu durumun en güzel örneklerinden biridir. Çocuk kitapları şiddetin bir çözüm aracı olmadığını göstermeli, çocukların şiddet ve kaba davranışlara karşı bir duyarlılık oluşturmalarına katkı sunmalıdır.

Robin Hood isimli eserde yer alan hırsızlık/el koyma ögesine yönelik bulgular Tablo 4'te sunulmuştur: 
Tablo 4. Incelenen eserlerde yer alan hırsızhk ögesine yönelik bulgular

\begin{tabular}{|c|c|c|}
\hline Kod & Kitap & $f$ \\
\hline \multirow{5}{*}{ 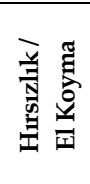 } & RH1 & 3 \\
\hline & RH2 & 8 \\
\hline & RH3 & 13 \\
\hline & RH4 & 15 \\
\hline & RH5 & 20 \\
\hline
\end{tabular}

Hırzızlık/el koyma iletilerine yer verilen Tablo 4'e göre bünyesinde hırsızlık veya el koyma iletisini en çok barındıran eser RH5 (20) kodlu kitaptır. En az barındıran ise RH1 (3) kodlu kitaptır. İçinde hırsızlığa veya el koymaya yönelik veri bulunmayan eser yoktur. Diğer eserler incelendiğinde ise RH4'ün (15), RH3'ün (13) ve RH2'nin (8) farklı yerde hırsızlık ögesine yer verdiği görülmektedir. "Zenginden alıp fakire verme" mantığ1 ile masumlaştırılmaya çalışılan bu iletiler; çocuklarda, gerekli olduğu durumlarda hırsızlık yapmanın veya bir şeylere zorla el koymanın bir zararının olmayacağı bilincini ortaya çıkarabilir. Eserlerde hırsızlık/el koyma ögesine yönelik örneklerden bazıları şöyledir:

- "SSerifin eviyle vedalaşsak iyi olur dostum" dedi Küçük John. "Ama gitmeden önce şerifin şu gümüş̧ takımlarından birazını almazsak olmaz. Hem bize şerifi anımsatır hem de önemli konuklarımızı bu kaplarla ağırlarız." (RH5, 59)

- Robin haline kahkahalarla güldü, güldü ve usta parmaklarryla cebindeki mektubu aşırdı. (RH4, 29)

- Çoğu kez Robin, günlük işlerden sıkılarak, Will Scarlet'ı adamlarının başında bırakıp kendisi tek başına dolaşmaya çıkıyordu. Bu gezintilerden çoğunlukla pusuya düşürülerek soyulacak zengin yolcularla ilgili bilgilerle dönüyordu. (RH3, 42)

- -Ne izni geri zekâhllar! diye bağırdı. Gidin kapıyı kırın! Evde, dolapta değerli ne varsa alip getirin.

Askerler, aceleyle tepeyi bir kez daha tırmandılar. Yirmi dakika sonra birkaç şişe şarapla geri döndüler. $($ RH2, 73)

- Küçük Jean söze karıştl:

-Günün birinde bu başrahip, sandiklarından bir kısmını Jorvaulx'dan Nothingam'a, orman yoluyla göndermek gafletinde bulundu. Doğrusunu isterseniz, biz de bu firsatı kaçıramazdık, tüm sandıklara el koyduk. (RH1, 13-14) 
Robin Hood adlı eserlerde yer alan hakaret ögesine yönelik bulgular Tablo 5'te verilmiştir:

Tablo 5. Incelenen eserlerde yer alan hakaret ögesine yönelik bulgular

\begin{tabular}{|c|c|c|}
\hline Kod & Kitap & $f$ \\
\hline \multirow{5}{*}{ 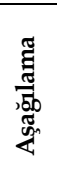 } & RH1 & 3 \\
\hline & RH2 & 3 \\
\hline & RH3 & 8 \\
\hline & RH4 & 7 \\
\hline & RH5 & 21 \\
\hline
\end{tabular}

Tablo 5'e göre eserlerde hakarete yönelik en fazla veri barındıran eser RH5 (21) kodlu kitaptır. Bunu sırasiyla RH3 (8), RH4 (7), RH1 (3) ve RH2 (3) takip etmektedir. Eserlerde hakaret ifadeleri olarak genellikle insanların fiziksel özellikleriyle dalga geçme (şişko, kel vb.), argo sözcükler kullanma (aptal, alçak, bunak, pis köylü $v b$.) veya başka bir ırka hakaret etme şeklinde yer almaktadır. Eserlerde geçen hakaret ögesine yönelik bazı örnekler şöyledir:

- "Kutsal bildiğim tüm şeyler adına!" diye bağırdı kral kaşlarm öfkeyle çatarak, "Böyle bir ihanete, savaştı̆̆ımı Araplarm kamplarında bile rastlanmaz. Bir de siz kendinize Hristiyan diyorsunuz!" (RH5, 232)

- Robin tepeden bakarak, "Aptal bir eşek gibi konuşuyorsun!" dedi. (RH3, 44)

- -Yă̆ tulumu, diye bağırdı. Kes sesini. Ben senden nasihat değil yemek istiyorum. (RH4, 91)

- Ruffolk, çevresine bir göz attı. Kaçma olanağı yoktu. Dev yapılı adam kapıyı tutmuştu. Kont:

-Pis köylü! (RH1, 81)

Robin Hood adlı eserlerde yer alan yalan ögesine yönelik bulgular Tablo 6'da verilmiştir:

Tablo 6. İncelenen eserlerde yer alan yalan ögesine yönelik bulgular

\begin{tabular}{|c|c|c|}
\hline Kod & Kitap & $f$ \\
\hline \multirow{5}{*}{ స్ స్ స్ర } & RH1 & 4 \\
\hline & RH2 & 2 \\
\hline & RH3 & 8 \\
\hline & RH4 & 9 \\
\hline & RH5 & 6 \\
\hline
\end{tabular}


Tablo 6'da Robin Hood adlı eserlerde yer alan yalan ögesine yönelik bulgulara yer verilmiştir. Bu bulgulara göre içinde en fazla yalan barındıran eser RH4 kodlu eserdir. Eserin 9 farklı yerinde yalan söylenmektedir. Bunu sirasiyla RH3 (8), RH5 (6), RH1 (4) ve RH2 (2) kodlu eserler takip etmektedir. Yalan ögesine yönelik örneklerden bazıları şöyledir:

- Robin Hood tekrar kahkahalarla gülerek:

-Tam üstüne bastın, dedi. İyi tahmin ettin. Beş yüz büyükbaş hayvanımız var. Kardeşlerim ve ben bir tekini olsun satamayız. Yoksa kasaplikla ne işim var benim? $(R H 4,70)$

- "Sen kimsin ki bana buralarda ne aradığımı soruyorsun" dedi adam yine kabaca. "Ben kralın orman korucularından biriyim" diye yanutladı Robin, "Garip kılıkl gezginlerden onlar korumak için burada bekliyorum."

"Garip kllklı olabilirim ama, gezgin falan değilim. Bir orman korucusu olduğuna göre, senden yardım isteyebilirim. Kralın buyruğuyla bir kanun kaçă̆ını arryorum... "Onun adamlarmdan biri misin yoksa?" diye sordu yabancl.

"Hayır, tanr korusun" dedi Robin... (RH5, 119)

\section{Tartışma ve Sonuç}

Bir toplumun geleceği, değerlerini benimsemiş insanlara bağlıdır ve eğitimin tek amacı öğrencilere bilgi ve beceri kazandırmak değildir. Eğitimin asli görevlerinden biri temel değerlerini kazanmış ve benimsemiş bireyler yetiştirmektir (MEB, 2019). Bu asli görevin gerçekleşmesi için çeşitli materyaller de kullanılabilmektedir. Bu materyallerden biri olan edebi ürünlerle çocukları karşılaştırmak, onların gerek duygusal ve zihinsel gelişimlerini desteklemek gerek çocuklara okuma sevgisi ve alışkanlığı kazandırmak açısından da büyük önem taşımaktadır (Özdemir ve İdi Tulumcu, 2017).

Bir eserin çocukların bilişsel, duyuşssal becerilerini geliştirebilmesi ve çocuğa göre olabilmesi için taşıması gereken bazı nitelikler vardır. Çocuk edebiyatı ürünleri sevgi, barış, iyilik, dürüstlük, iyimserlik gibi konular etrafında yazılmalı ve çocuklara insan, doğa, hayvan sevgisi kazandırmalıdır (Aktaş ve Uzuner Yurt, 2017). Ayrıca çocuk edebiyatı ürünlerinde şiddet, korku, düşmanlık, ırkçlık, cinsiyetçilik, kötümserlik, kin, nefret, argo gibi unsurlara da yer verilmemelidir (Demirel, 2011, s. 53; Enginün, 2006; Nas, 2004, s. 91; Oğuzkan, 1997, s. 51). Millı̂ Eğitim Bakanlığı da ders kitaplarına alınması ge- 
reken metinlerin özelliklerini sıralarken metinlerin argo, küfür, olumsuz örnek oluşturabilecek davranışlar, cinsellik, şiddet vb. içeren unsurları barındırmaması (MEB, 2019, s. 18) gerektiğinden bahsetmektedir. Ders kitabında yer almaması gereken bu unsurların çocuk edebiyatı ürünlerinde de bulunmaması gerektiğini söylemek yanlış olmayacaktır. Tüm bu verilerden hareketle Robin Hood adlı eserler, bu olumsuz unsurları taşıyı taşımadıklarına göre incelenmiştir.

Eserlerin incelenmesi sonucunda ortaya çıkan ve çocuk edebiyatı ürünlerinde bulunmaması gereken unsurlardan biri kahramanların içki içmesidir. Çocuklara model olması gereken eser kahramanlarının içki içmeleri ve özellikle de bu kahramanların herkes tarafından saygıyla anılıyor olması, çocukların onları her hâliyle örnek almasına neden olabilmektedir. Bu bağlamda, Robin'in ve arkadaşlarının içki içmeleri çocuklar üzerinde etki edebilecektir. Robin Hood adlı eserler incelendiğinde içki/alkol unsurunun çokça geçtiği görülmektedir. İçinde bu olumsuz unsura yönelik en fazla veri barındıran eser RH4 kodlu kitaptır. Kitabın 65 farklı yerinde bira, şarap veya diğer alkollü içeceklerle ilgili ifadeler bulunmaktadır. Bunu sırasıyla RH5 (55), RH3 (40), RH1 (19) ve RH2 (3) takip etmektedir. Literatürde farklı çocuk edebiyatı ürünlerinin incelenmesine yönelik araştırmalarda da benzer sonuçlarla karşılaşılmaktadır. Ömer Seyfettin hikâyelerini çocuk edebiyatı açısından inceleyen Aktaş ve Uzuner Yurt (2017) da araştırmalarında içki, kumar gibi çocukları olumsuz etkileyecek ifadelerin eserlerde geçtiğini tespit etmişlerdir.

Araştırmada ele alınan bir diğer unsur da şiddet ögesidir. Bu olumsuz unsur da incelenen eserlerde sıkça görülmektedir. Elde edilen bulgulara göre şiddet iletilerini içinde en çok barındıran eser RH4 (45) kodlu eserdir. Bunu sirasiyla RH3 (35), RH5 (32), RH2 (18) ve RH1 (6) takip etmektedir. İncelenen eserlerin içinde şiddet barındırmayan bir kitap yoktur. Şiddet ögesi genellikle karşımıza savaş, kavga, zorbalık şekillerinde çıkmaktadır. "İstediğini yaptıramadığı zaman döverek/zorla yaptırabilmesi" mesajı çocuklara bu eserler aracılığıyla iletilebilecek olumsuz mesajlardandır. Literatürde çocuk edebiyatında ürünlerinde şiddet ögesini incelemeye yönelik hazırlanan çalışmalarda (Bilgin, 2011; Dağlığlu ve Çakmak, 2009; Fırat, Güleç ve Şahin, 2013; Öztürk ve Giren, 2016; Sever, 2002; Yılmaz ve Destegüloğlu, 2019) da farklı eserlerde de şiddet ögesinin bulunduğu ve bunların çocuklar üzerinde olumsuz etkiye sahip oldukları ortaya çkarılmıştır. Sever'e (2005) göre çocuk kitaplarında 
baskı ve şiddetin olumlu bir durum gibi gösterilmemesi gerekmektedir. Ayrıca şiddetin sorunların çözümü için kullanılabilecek yollardan biri olarak da gösterilmemesi gerekmektedir.

Altınköprü'ye (2005) göre çocuk kitapları hırsızlık gibi kötü alışkanlıkların önüne geçilmesini sağlayacak nitelikte olmalıdır. Eserler hırsızlık $v b$. davranışları olumlamamalıdır. Robin Hood adlı eserler incelendiğinde hırsızlığın kitapların hepsinde yer aldığı görülmektedir. Bulgulara göre bünyesinde hırsızlık ile ilgili ifadeleri en çok barındıran eser RH5 (20) kodlu kitaptır. En az barındıran eser ise RH3 (3) kodlu kitaptır. İçinde hursızlığa yönelik veri bulunmayan eser yoktur. Diğer eserler incelendiğinde ise RH4'ün (15), RH3'ün (13) ve RH2'nin (8) farklı yerde hırsızlık ögesine yer verdiği görülmektedir. Eserlerde ana karakterin zengin insanlardan soyduğu kıymetli eşyaları, paraları fakirlere pay etmesi, zenginden al fakire ver algısı yaratarak, erdemli bir davranış olarak gösterilmektedir (Kardaş ve Kardaş, 2018, s. 115). Robin Hood'un yaptı̆̆ı hırsızlıkları veya insanların mallarına zorla el koymasını masum bir sebebe dayandırmaya çalışmak da o davranışları yapmak kadar yanlıştır. Çünkü her ne sebeple olursa olsun hırsızlık yapmak veya birilerinin malını zorla almak yanlış ve suçtur. Amacı her ne olursa olsun hırsızlık yapması Robin Hood'u çocuklara uygun bir model olmaktan uzağa taşımaktadır (Kardaş ve Kardaş, 2018).

Çocuğa göre olmayan bir diğer unsur da hakaret içeren ifadelerdir. İncelenen eserler içinde hakarete yönelik en fazla veri barındıran RH5 (21) kodlu kitaptır. Bunu sırasiyla RH3 (8), RH4 (7), RH1 (3) ve RH2 (3) takip etmektedir. Eserlerde hakaret ifadeleri olarak genellikle insanların fiziksel özellikleriyle dalga geçme (şişko, kel vb.), argo ifadeler kullanma (aptal, alçak, bunak, pis köylü $v b$.) veya başka bir ırka hakaret etme şeklinde yer almaktadır. İncelenen eserler bu yönleriyle de çocuklara olumsuz örnek teşkil etmektedir. Çünkü çocuklar bu eserleri örnek alarak insanların fiziksel özellikleriyle dalga geçebilirler veya insanlara hakaret etme davranışlarını sergileyebilirler.

Çalışmada ele alınan son öge ise yalandır. Eserlerden elde edilen bulgulara göre içinde en fazla yalan barındıran kitap RH4 kodlu eserdir. Eserin 9 farklı yerinde yalan söylenmektedir. Bunu sırasiyla RH3 (8), RH5 (6), RH1 (4) ve RH2 (2) kodlu eserler takip etmektedir. Özellikle Robin Hood'un insanları kandırmak için yalana başvurması ve söylediği bu yalanlar sayesinde amacına ulaşması çocukları da yalan söylemeye yönlendirebilecek bir durumdur. 
Robin Hood isimli yayınların farklı yayınevleri tarafından basılan baskıları incelendiğinde; sayfa sayısı, puntosu, baskıya dahil edilen bölümleri gibi unsurlar açısından kimi farklılıklar göstermeleriyle birlikte hepsinde çocuğa göre olmayan ögelerin çokça yer aldığı tespit edilmiştir. Yayınlardan birinde içki ögesi fazla geçerken diğerinde şiddet ögesi bir başkasında ise hırsızlık çokça yer almaktadır. Bu durum hangi baskısı olduğuna bakmaksızın Robin Hood isimli kitapların çocuklar için uygun olmadığı sonucunu ortaya çıkarmaktadır.

Çocuk edebiyatı ürünlerinde karşımıza çıkan kahramanların çocuklara iyi birer model olması gerekmektedir. Kahramanlar aracılığılla çocuklara olumlu mesajlar gönderilirken davranışlarıyla da kahramanların çocukları iyiye yönlendirme işlevini üstlenmesi gerekmektedir. Çalışmadan elde edilen veriler Robin Hood'un çocuklar için örnek davranışlar sergilemediğini ve birçok olumsuz tutum ve davranışa sahip olduğunu ortaya çıarmıştır. Benzer şekilde Kardaş ve Kardaş (2018) tarafından yapılan araştırmada da Robin Hood karakterinin haksızlığa haksızlıkla cevap veren bir çeşit eşkıya olduğu gerçeğinin arka plana atıldığı ve Robin Hood'un masum birini öldürmesinin, maksadı her ne olursa olsun hırsızlık yapmasının onu çocuklar için uygun bir model olmaktan çıkardığı sonuçlarına ulaşılmıştır. Fakat yapılan araştırmalar göstermektedir ki doğru edebi ürünlerin kullanılması öğrencilerin değer geliştirmelerine, bu değerleri benimsemelerine ve onların karakter gelişimine katkı sağlamaktadır (Alan, Biçer ve Hüküm, 2016; Çiçek, 2016; Demirel ve Kökçü, 2019; Karaca ve Temizyürek, 2017; Karatay, 2011; Karatay, Destebaş1 ve Demirbaş, 2015; Yılmaz, 2016). Bu yüzden öğrencilerin olumsuz alışkanlıklara yönelmelerine neden olan eserler yerine, onları iyiye, güzele, doğruya yönlendiren eserleri tercih etmek, değer aktarımı ve karakter oluşturma süreçlerinde aileye, çevreye ve eğitimcilere büyük fayda sağlayacaktır. Çalışmamıza kaynak olan eser Robin Hood, barındırdığı mesajlarla ve eser kahramanlarının davranışlarıyla çocuklarda olumsuz davranışların oluşmasına neden olacaktır. Robin Hood'u model olarak seçen bir çocuğun, kahramanın olumsuz davranışlarını da örnek alması kaçınılmazdır. Bu nedenle Robin Hood isimli eserlerin çocuk edebiyatı ürünü olarak kullanılmasının ve çocuklara okutulmasının sakıncalı olacağı düşünülmektedir.

Elde edilen sonuçlardan hareketle şu öneriler sunulabilir: 
- Çocuk kitabı olarak kullanılan eserlerdeki karakterler, çocukların model olarak seçeceği kahramanlardır. Bu yüzden eserlerdeki kahramanların çocuklara olumsuz özellikler kazandıracak yapıda olmaması gerekir.

- Çeviri eserler toplumsal veya kültürel açıdan farklılıklar gösterebilir. Bir toplumda normal olarak karşılanabilen bir unsur diğer toplumun değerleriyle örtüşmeyebilir. Bu nedenle eserlerin çevirisi yapılırken toplumun özelliklerinin dikkate alınması gerekmektedir.

- Robin Hood gibi kahraman olarak görülen fakat taşıdığı özellikler açısından çocuklar için uygun bir model olmayan karakterlerin bulunduğu eserler çocuk edebiyatı ürünü olarak kullanılmamalıdır. 


\section{EXTENDED ABSTRACT}

\section{Elements that are Not for the Child in Robin Hood * \\ Yakup Alan \\ Kilis 7 Aralık Üniversity}

Robin Hood is an English folk hero set in the English folk tales that is estimated to have lived in the 12th century. In many sources created by compiling folk tales, Robin is considered as an outlaw against King John. Robin Hood's way of struggle against injustices has an important effect on him being an English hero. This struggle has been the subject of many books and plays. Sir Walter Scott, Howard Pyle and Roger L. Green are some of the authors who wrote the life and experiences of Robin Hood. Although there are similarities in some aspects in the works titled Robin Hood created by compiling folk stories, there also a lot of differences. For example, the reason for Robin's being an outlaw in one work is based on killing one of the rangers, while in the other it is based on the killing of the soldiers' mother. Or, in one work, Robin is depicted as a farmer, while in another as the son of a noble person. Howard Pyle's version of the Robin Hood compilations is the most popular among the translated books. On the other hand, Roger L. Green's compilation is another Robin Hood book, which was translated as well. There are also differences in the translations since the omission of some parts from the compilations of stories does not affect the integrity of the subject. It may cause us to encounter different Robin Hood characters due to both being presented differently by the compilers and not having all of the sections in some translations.

Document review was employed in the study. Document review involves the analysis of written materials that contain information about the facts and phenomena that are aimed to be examined (Yıldırım and Şimşek, 2016, p. 189). The reason for employing the document review in the study is that the studied works are the main data source.

The materials examined in the study, in which the works titled Robin Hood were handled, were created by using criterion sampling. The main understanding in criterion sampling is to study the conditions that meet predetermined criteria. The criteria can be created by the researcher as well as a previously prepared criteria list can be used (Yıldırım and Şimşek, 2016, p. 
122). In this study, with the idea that heroes have important roles in children's literature, the criterion of "what may be the negative features of a hero that is accepted by everyone" was accepted and the work titled "Robin Hood" was decided to be examined due to his acceptance as a hero by everyone. Books published by five publishers were included in the study. In the selection of publishers, the criteria such as being easily accessible, affordable, and being among the best-selling Robin Hood books on the book sales websites were taken into consideration. Furthermore, it was noted that the selected works were books written by different compilers. Therefore, the analysis of the hero was ensured by choosing both the works that everyone can access easily and the works compiled by different authors. The reason for examining five different publications in the research is to consider Robin Hood in all aspects described in different works.

The works were initially read twice by the researcher and an idea was formed about the works. Then, in order to reveal the themes determined, the works were read again by the researcher and data was obtained by profiling. A book chosen randomly by another expert besides the researcher was examined and the data were compared for reliability.

Descriptive analysis was used in the analysis of the data obtained. According to this analysis method, the data are summarized and interpreted according to the previously determined themes. Direct quotations are frequently included in descriptive analysis (Yıldırım and Şimşek, 2016, p. 239). The data obtained in the study were coded according to the themes (alcohol, violence, defamation, lying, cheating, theft, etc.) that should not be found in children's literature; their frequencies were determined and presented in tables. Furthermore, examples from the works are presented to support the data.

The formula of Miles and Huberman (1994) was used in order to ensure the reliability of the study. Inter-coder consistency was examined and coding reliability was found as .83 . This result shows that the coding is reliable.

The future of a society depends on people who have embraced its values, and education is not the sole purpose of equipping students with knowledge and skills. One of the primary duties of education is to train individuals who have gained and adopted their basic values (MEB, 2019). Various materials can also be used to perform this essential task. It is also important to introduce the literary products, which is one of these materials, to children to support 
their emotional and mental development, and to give them a love and habit of reading (Özdemir and İdi Tulumcu, 2017).

The heroes that we encounter in children's literature works should be good models for children. Positive messages are conveyed to the children through the heroes but the heroes also have to undertake the function of directing the children for the better with their behaviors. The data obtained from the study revealed that Robin Hood does not exhibit exemplary behaviors for children and has many negative attitudes and behaviors. Similarly, in the study conducted by Kardaş and Kardaş (2018), the fact that the Robin Hood character is a kind of outlaw treating people unfairly was ignored and it was concluded that Robin Hood's killing an innocent person or stealing for whatever purpose makes him an unsuitable role model for children. However, the studies show that the use of the correct literary products contributes to the character development of students as well as contributing them to develop values and to adopt these values (Alan, Biçer and Hüküm, 2016; Çiçek, 2016; Demirel and Kökçü, 2019; Karaca and Temizyürek, 2017; Karatay, 2011 ; Karatay, Destebaşı and Demirbaş, 2015; Yılmaz, 2016). Therefore, choosing works that direct the students towards what is good, beautiful and correct instead of choosing the works that cause students to turn towards negative habits will help the family, the society and educators in value transfer and character formation processes. The source of our work, Robin Hood, will cause negative behaviors in children with the messages that it contains and the behaviors of the heroes in the work. It is inevitable for a child who chooses Robin Hood as a role model to take the negative behaviors of the hero as an example. Therefore, it is thought that it will be undesirable to use Robin Hood as a children's literature work and to teach it in the education of the children.

\section{Kaynakça / References}

Aktaş, E. ve Uzuner Yurt, S. (2017). The factors being not "proper for child" in the stories of Ömer Seyfettin in terms of children' literature. International Online Journal of Educational Sciences. doi:10.15345/iojes.2017.01.014

Alan, Y. (2012). Türkçe ders kitaplarmdaki okuma ve serbest okuma metinlerinin dini ve ahlaki değerler açısından incelenmesi. Yayımlanmamış yüksek lisans tezi. Abant İzzet Baysal Üniversitesi Eğitim Bilimleri Enstitüsü Türkçe Eğitimi Ana Bilim Dalı, Bolu. 
Alan, Y., Hüküm, M. ve Biçer, N. (2016). Çocuğa görelik ilkesi açısından Cemal Süreya'nın Aritmetik İyi, Kuşlar Pekiyi adlı eseri 1. Uluslararası Sosyal Bilimler Sempozyumu, sunulmuş bildiri, Elazı ̆̆: Asos Yayınları. 222-233.

Altınköprü, T. (2005). Batı çocuk edebiyatının olumsuz etkileri. İstanbul Eğitim ve Kültür Dergisi, 9, 64-65.

Bilgin, H. (2011). 5-6 yaş çocuklarnna yönelik 1990-2010 Yilları arasında basılan resimli kitapların çocuğa görelik kavramına göre incelenmesi. Yayımlanmamış yüksek lisans tezi. Marmara Üniversitesi Eğitim Bilimleri Enstitüsü, İstanbul.

Büyüköztürk, Ş. vd. (2008). Bilimsel araştırma yöntemleri. Ankara: Pegem Akademi Yayınları.

Çiçek, M. (2016). İsmet Bertan, Sevim Ak ve Görkem Yeltan'ın çocuk romanlarındaki başkahramanların çözümlenmesi. The Journal of Social Sciences, 3(7), 113-113. doi:10.16990/SOBIDER.244

Dağlıoğlu, H. E. ve Çakmak, Ö. Ç. (2009). Okul öncesi çocuklarına yönelik yayınlanan hikâye kitaplarının şiddet ve korku öğeleri açısından incelenmesi. Türk Kütüphaneciliği, 23(3), 510-534.

Demirel, Ş. (2011). Edebî metinlerle çocuk edebiyatı. Ankara: Pegem Yayıncılık.

Demirel, Ş. ve Kökçü, Y. (2019). Richard Bach'ın Martı adlı eserinin çocuğa görelik bağlamında incelenmesi. Firat Üniversitesi Sosyal Bilimler Dergisi, 29(2), 149-161. doi:10.18069/firatsbed.661315

Enginün, İ. (2006). Çocuk edebiyatı ve çocuk kitapları. Eğitim Fakültesi Dergisi, 19(1), 213-222.

Firat, H., Güleç, H. ve Şahin, Ç. (2013). Okul öncesi dönem çocuklarına yönelik hazırlanan masal ve öykü kitaplarının korku ve şiddet öğeleri açısından incelenmesi. International Journal of Social Science, 6(5), 217-241.

Gökçek, B. S. (2007). 5-6 yaş çocukları için hazırlanan karakter eğitimi programının etkisinin incelenmesi. Yayımlanmamış yüksek lisans tezi. Marmara Üniversitesi Eğitim Bilimleri Enstitüsü İlköğretim Ana Bilim Dalı Okul Öncesi Eğitimi Bilim Dalı, İstanbul.

Gönen, M. ve Veziroğlu, M. (2013). Çocuk edebiyatının genel hedefleri. M. Gönen (Ed.), Çocuk Edebiyatı içinde (s. 1-12). Ankara: Eğiten Kitap.

Green, R. L. (1995). Robin Hood. İstanbul: Epsilon Yayıncillk.

Güleryüz, H. (2003). Yaratıcı çocuk edebiyatı. Ankara: Pegem A Yayıncılık.

Karaca, G. ve Temizyürek, F. (2017). Sevim Ak'ın öykülerinin çocuğa görelik ilkesi açısından incelenmesi. Bartın Üniversitesi Eğitim Fakültesi Dergisi, 6(1), 177-195. doi:10.14686/buefad.263572 
Karakuş Tayşi, E. (2019). Sevim Ak'ın öykülerinin duyarlık eğitimi açısından incelenmesi. Dil ve Edebiyat Araştırmaları, 19, 303-324. doi:10.30767/diledeara.542628

Karataş, E. (2014). Çocuk edebiyatında "karakter" kavramı. Muğla Sıtkı Koçman Üniversitesi Sosyal Bilimler Enstitüsü Dergisi, 33, 60-79.

Karatay, H. (2011). Karakter eğitiminde edebi eserlerin kullanımı. Turkish Studies, 6(1), 1398-1412. doi:10.7827/TurkishStudies.2191

Karatay, H., Destebaşı, F. ve Demirbaş, M. (2015). Çocuk edebiyatı ürünlerinin 6, 7 ve 8. sınıf öğrencilerinin karakter gelişimine etkisi. Erzincan Üniversitesi Sosyal Bilimler Enstitüsü Dergisi.

Kardaş, D. M. ve Kardaş, D. (2018). En çok okunan çeviri çocuk kitaplarından bazıları üzerine bir araştırma. Osmanlı Mirası Araştırmaları Dergisi, 5(11), 103-116. doi:10.17822/omad.2018.95

Kavcar, C. (1999). Edebiyat ve eğitim. Ankara: Engin Yayınevi.

Kuru, H. ve Keklik, S. (2016). Ayşe Yamaç'ın çocuk romanlarının değerler eğitimi açısından incelenmesi. Sosyal Bilimler Dergisi, 10, 217-237.

MEB. (2019). Türkçe öğretim programı. Ankara: Milli Eğitim Bakanlığı Talim ve Terbiye Kurulu Başkanlığı.

Miles, M. B. ve Huberman, M. A. (1994). Qualitative data analysis. London: Sage Publication.

Nas, R. (2004). Örneklerle çocuk edebiyatı. Bursa: Ezgi Kitabevi.

Oğuzkan, A. F. (2013). Çocuk edebiyatı (10. bs.). Ankara: Anı Yayıncılık.

Oğuzkan, A.F. (1997). Yerli ve yabancı yazarlardan örneklerle çocuk edebiyatı. Ankara: Emel Yayıncilik.

Özdemir, E. (1983). Anadili olarak Türkçe öğretimi. Türk Dili Dergisi, Dil Öğretimi Özel Sayısı, 379-380.

Özdemir, M. ve İdi Tulumcu, F. (2017). Değerler eğitiminde edebi eserlerden yararlanma: Fatma Aliye'nin Muhadarat romanı örneği. Sakarya University Journal of Education, 720-729. doi:10.19126/suje.377548

Öztürk, M. ve Giren, S. (2016). Okul öncesi dönemdeki çocuklar için hazırlanan hikâye kitaplarındaki korku ve şiddet öğelerinin incelenmesi. Uluslararası Türkçe Edebiyat Kültür Eğitim Dergisi, 5(4), 2095-2108.

Pyle, H. (2012). Robin Hood. İstanbul: Akvaryum Yayınevi.

Pyle, H. (2014). Robin Hood. İstanbul: Parıltı Yayıncilık.

Pyle, H. (2016a). Robin Hood. İstanbul: Arkadaş Çocuk Yayınevi.

Pyle, H. (2016b). Robin Hood. İstanbul: Yapı Kredi Yayınları. 
Sever, S. (2002). Çocuk kitaplarına yansıtılan şiddet :Milli Eğitim temel yasası ve çocuk haklarına dair sözleşme bağlamında bir değerlendirme. Ankara Üniversitesi Ĕ̆itim Bilimleri Fakültesi Dergisi, 35(1-2), 26-37.

Sever, S. (2005). Çocuk, yazın ve yaşam. Çoluk Çocuk Dergisi, 46 30-34.

Sever, S. (2012). Çocuk ve edebiyat. (6. Baskı). İzmir: Tudem.

Şirin, M. R. (2000). 99 soruda çocuk ve edebiyat. İstanbul: Çocuk Vakfı Yayınları.

Turan, L. (2006). Violence and death in stories of war period writer Ömer Seyfettin. https://files.eric.ed.gov/fulltext/ED493901.pdf adresinden alınmıştır.

Varışoğlu, B. ve Tuzcuoğlu Aksin, Ş. H. (2019). Andrew Clements'in Bunun Adı Findel adlı çocuk edebiyatı eserinin çocuğa görelik açısından incelenmesi. RumeliDE Dil ve Edebiyat Araştırmaları Dergisi, 639-656. doi:10.29000/rumelide.619651

Yıldırım, A. ve Şimşek, H. (2016). Sosyal bilimlerde nitel araştırma yöntemleri (10. bs.). Ankara: Seçkin Yayıncılık.

Yılmaz, O. (2016). Kurgusal nitelikli çocuk kitapları ve karakter eğitimi. Ana Dili Eğitimi Dergisi, 4(3), 311. doi:10.16916/aded.36213

Yılmaz, O. ve Destegüloğlu, B. (2019). Çocuk kitaplarına yansıyan şiddet. İlköğretim Online, 1099-1112. doi:10.17051/ilkonline.2019.610732

\section{Kaynakça Bilgisi / Citation Information}

Alan, Y. (2020). Robin Hood isimli eserlerde çocuğa göre olmayan ögeler. OPUS-Uluslararası Toplum Araştırmaları Dergisi, 16(28), 1296-1318. DOI: 10.26466/opus.682939 